\title{
Az egészségügyi szimulációs oktatás jelene és jövője Magyarországon
}

\author{
Bogár Péter Zoltán dr. ${ }^{1,2}$. Tóth Luca dr. ${ }^{2,3,4}$ - Rendeki Szilárd dr. ${ }^{5,6}$ \\ Mátyus László dr. ${ }^{7}$ - Németh Norbert dr. ${ }^{8,9}$ - Boros Mihály dr. ${ }^{10}$ \\ Nagy Bálint dr. ${ }^{6}$ - Nyitrai Miklós dr. ${ }^{1,2}$ - Maróti Péter dr. ${ }^{1,2,5}$
}

\author{
${ }^{1}$ Pécsi Tudományegyetem, Általános Orvostudományi Kar, Biofizikai Intézet, Pécs \\ ${ }^{2}$ Pécsi Tudományegyetem, Általános Orvostudományi Kar, 3D Nyomtatási és Vizualizációs Központ, Pécs \\ ${ }^{3}$ Pécsi Tudományegyetem, Általános Orvostudományi Kar, Klinikai Központ, Idegsebészeti Klinika, Pécs \\ ${ }^{4}$ Pécsi Tudományegyetem, Általános Orvostudományi Kar, Transzlációs Medicina Intézet, Pécs \\ ${ }^{5}$ Pécsi Tudományegyetem, Általános Orvostudományi Kar, Szimulációs Oktatási Központ, Pécs \\ ${ }^{6}$ Pécsi Tudományegyetem, Általános Orvostudományi Kar, Aneszteziológiai és Intenzív Terápiás Intézet, Pécs \\ ${ }^{7}$ Debreceni Egyetem, Általános Orvostudományi Kar, Biofizikai és Sejtbiológiai Intézet, \\ Biomatematikai Tanszék, Debrecen \\ ${ }^{8}$ Debreceni Egyetem, Általános Orvostudományi Kar, Sebészeti Intézet, Sebészeti Mútéttani Tanszék, Debrecen \\ ${ }^{9}$ Debreceni Egyetem, Általános Orvostudományi Kar, Interaktív Orvosi Gyakorlati Központ, Debrecen \\ ${ }^{10}$ Szegedi Tudományegyetem, Általános Orvostudományi Kar, Sebészeti Mútéttani Intézet, Szeged
}

\begin{abstract}
Az egészségügyi, orvosi szimulációs oktatás alapja, hogy klinikai szituációkat, gyakorlati feladatokat modellez szimulátorok, számítástechnikai megoldások, esetleg humán szereplők segítségével. Így az oktatott a legvalósághúbb környezetben sajátíthatja el a készségeket. A közleményben bemutatjuk a szimulációs oktatás múltját, technológiai hátterét, valamint a szimulációs oktatás jelenlegi helyzetét Magyarországon, melynek megkérdőjelezhetetlen szerepe van az egészségügyi felsőoktatásban. Számos pozitív hatása van hallgatók és oktatók számára, továbbá az intézetek számára is számtalan előnyt tartogat. Az egységek feladata, hogy hidat teremtsen az elméleti és a gyakorlati képzés között, felkészítve a hallgatókat a valódi orvosegészségügyi életpálya kihívásaira. Bár a terület több évszázada ismert módszertan az orvos- és egészségtudományi képzésben, csak a XXI. században indult jelentős fejlődésnek a technológia robbanásszerú előrehaladásának köszönhetően. Az innovatív megoldások révén egyre élethúbben lehet modellezni bonyolultabb orvosi feladatokat is. Már hazánkban is használják az oktatás során a 3D nyomtatott segédeszközöket, virtuális- és kiterjesztettvalóság-megoldásokat. A magyarországi „Skill Labor Hálózat” fejlesztése mellett a szimulációs oktatás hazai módszertanának kialakítása is megkezdődött, ennek sikerességét jelzi több, oktatást segítő kézikönyv megjelenése is. A hálózat négy egyetemi skillközpontot és 16 oktató kórházat foglal magában. A skilllaborok eddig hiányzó láncszemek voltak az elméleti és a klinikai oktatás között, melyekben magas szakmai színvonalú gyakorlati készségeket sajátíthatnak el a hallgatók mind a graduális, mind a posztgraduális képzés során. A kezdeti fejlesztések sikeresnek tekinthetők, ezt tükrözi a nagy érdeklődés, a résztvevoók száma és a hallgatók pozitív visszajelzései is. Közleményünk átfogó jelleggel betekintést ad a magyarországi egészségügyi szimulációs oktatás jelenlegi helyzetébe, illetve felveti a potenciális fejlesztési irányokat, gyakorlati példákkal szemléltetve. Orv Hetil. 2020; 161(26): 1078-1087.
\end{abstract}

Kulcsszavak: szimulációs képzés, virtuális valóság, egészségügyi felsőoktatás, szimulátor, innováció

\section{The present and the future of medical simulation education in Hungary}

Simulation-based medical education aims to model clinical situations and tasks using simulators, computers or even human beings. By using this system, the students are able to learn and master technical, also non-technical skills in lifelike situations. This publication contains a historical review of simulation-based education system, and its actualities in Hungary. Simulation has an unquestionable role in medical education. It is beneficial for the students, for the teachers, and for the teaching hospitals as well, since it saves clinical equipment and reduces the human burden. Its main purpose is to establish connection between theoretical and practical competencies, preparing the students for real medical challenges. Simulation has been a known teaching method for centuries, but only the 21 st century brought real breakthrough due to the sudden development of technology. As a result of the recent years' innovative 
development and accepted innovative solutions, the modeling of complex medical procedures turned into more realistic. In Hungary, 3D-printed tools, virtual reality and augmented reality approaches are already adopted for education purposes. The national simulation network contains 3 universities and 16 hospitals. The initial developments are shown to be successful, as simulation-based training is progressively involved in undergraduate and post-graduate education, and the overall feedback is positive from the involved students. The evolvement of comprehensive national methodology for education has started also, by publishing reference books. This review is about the state of the national simulation education and offers development possibilities.

Keywords: simulation training, virtual reality, medical education, simulator, innovation

Bogár PZ, Tóth L, Rendeki Sz, Mátyus L, Németh N, Boros M, Nagy B, Nyitrai M, Maróti P. [The present and the future of medical simulation education in Hungary]. Orv Hetil. 2020; 161(26): 1078-1087.

(Beérkezett: 2020. február 14.; elfogadva: 2020. március 21.)

\section{Rövidítések}

3D = háromdimenziós; ÁEEK = Állami Egészségügyi Ellátó Központ; ALS = (advanced life support) emelt szintü újraélesztés; ÁOK = Általános Orvostudományi Kar; AR = (augmented reality) kiterjesztett valóság; BLS = (basic life support) alapszintű újraélesztés; CASE = (comprehensive anesthesia simulation environment) átfogó érzéstelenítési szimulációs környezet; DICOM = (digital imaging and communications in medicine) digitális képalkotás és kommunikáció az orvoslásban; EFOP = Emberi Erőforrás Fejlesztési Operatív Program; $\mathrm{EKG}=$ elektrokardiográfia $;$ GAS $=($ Gainesville anesthesia si mulator) Gainesville érzéstelenítésszimulátor; HEFOP $=\mathrm{Hu}-$ mánerőforrás-fejlesztési Operatív Program; ILKA = Ilias Képzés Adminisztráció; KMOP = Közép-magyarországi Operatív Program; LCMS = (learning and content management system $)$ tanulási és tartalomkezelő rendszer; ROP = Regionális Operatív Programok; SMI = Sebészeti Mútéttani Intézet; SZOTA = Szimulációs Oktatást Támogató Audiovizuális Rendszer; SZTE = Szegedi Tudományegyetem; TÁMOP = Társadalmi Megújulás Operatív Program; VR = (virtual reality) virtuális valóság

A szimulációs egészségügyi, orvosi oktatás alapja, hogy valós klinikai helyzeteket, szituációkat vagy megoldandó gyakorlati feladatokat modellez szimulátorok, oktatási eszközök, számítástechnikai megoldások, egyes esetekben pedig humán szereplők bevonásával, annak érdekében, hogy az oktatott a lehető legvalósághúbb környezetben és módon sajátíthassa el az egyes technikai vagy nem technikai készségeket [1]. Az egészségügyi felsőoktatásban napjainkban megkérdőjelezhetetlen fontosságú a szimulációs képzési forma. Számos előnyét nemzetközi tanulmányok egész sora támasztja alá [2-10]. Mind a hallgatók, mind az oktatók számára pozitív hatásokkal bír, oktatásmódszertani és -technikai szempontból egyaránt. Növeli a hallgatók biztonságérzetét, fejleszti motoros és szenzoros készségeiket, javítja térlátásukat, fejleszti kommunikációs képességeiket. Az oktatók számára lehetőséget ad az érdekes esetek megismétlésére és a standard ellátási protokollok egységes demonstrálására, moduláris oktatást tesz lehetővé, illetve az oktatási kör- nyezet is komfortosabb a klinikai lehetőségekkel összevetve. A képzéseket megtartó intézmények számára szintén komoly potenciált tartogat, végeredményben egyes tartalmi elemek költséghatékonyabbak, biztonságosabbak - hiszen nincs szükség például steril környezetre, nem terheli a kórházi ellátási rendszer személyi és eszközállományát, valamint a páciensek biztonsága is javul a szimulációs képzésnek köszönhetően. Hazánkban is felismerték ennek fontosságát, és a 2010-es évek elején megkezdődött a szimulációs oktatási központok (skilllaborok) szervezett kialakítása, melyek központjai - több kórház és más felsőoktatási intézmény mellett - az orvosképző egyetemeken (Budapest, Debrecen, Pécs, Szeged) alakultak ki (1. táblázat).

Az egészségügyi szimulációs oktatás célja nem az, hogy helyettesítse a betegágy melletti, klinikai oktatást, hanem az, hogy hidat teremtsen az elméleti és a gyakorlati képzés között, felkészítve a hallgatókat a valódi orvosegészségügyi életpálya kihívásaira. Emellett másik alapvető feladata, hogy valódi csapatmunkára oktassa a

\begin{tabular}{|c|c|c|}
\hline $\begin{array}{l}\text { A szimul } \\
\text { szemben }\end{array}$ & iós oktatási forma előı & i a tradicionális oktatással \\
\hline $\begin{array}{l}\text { Előnyök } \\
\text { a hallgatók számára }\end{array}$ & $\begin{array}{l}\text { Előnyök } \\
\text { az oktatók számára }\end{array}$ & $\begin{array}{l}\text { Előnyök } \\
\text { az intézmények } \\
\text { számára }\end{array}$ \\
\hline $\begin{array}{l}\text { A rizikómentes } \\
\text { gyakorlás lehetősége }\end{array}$ & Ismételhető esetek & Költséghatékonyság \\
\hline $\begin{array}{l}\text { Ritka és magas } \\
\text { kockázatú betegsé- } \\
\text { gek, esetek megisme- } \\
\text { rése }\end{array}$ & $\begin{array}{l}\text { Modularitás: } \\
\text { graduális, posztgra- } \\
\text { duális szintek } \\
\text { oktatása }\end{array}$ & $\begin{array}{l}\text { Oktatásszervezési } \\
\text { előnyök a klinikai } \\
\text { oktatásban }\end{array}$ \\
\hline $\begin{array}{l}\text { Önbizalom-növelés, } \\
\text { a stressz-szint } \\
\text { csökkentése }\end{array}$ & $\begin{array}{l}\text { Lehetőséget ad az } \\
\text { objektív értékelésre, } \\
\text { standardizálásra }\end{array}$ & $\begin{array}{l}\text { Jelentős marketingté- } \\
\text { nyező és hallgatóielé- } \\
\text { gedettség-növelő } \\
\text { hatás }\end{array}$ \\
\hline $\begin{array}{l}\text { Nem technikai } \\
\text { skillek, készségek } \\
\text { elsajátítása (kommu- } \\
\text { nikáció, csapatmun- } \\
\text { ka, empátia stb.) }\end{array}$ & $\begin{array}{l}\text { Kényelmi szempon- } \\
\text { tok (eszközök, } \\
\text { kontrollált környezet } \\
\text { stb.) }\end{array}$ & Minőségbiztosítás \\
\hline
\end{tabular}


résztvevőket, hiszen a betegellátás során a szakdolgozóknak és az orvosoknak közösen kell elvégezniük a mindennapi feladataikat. A szimulációs oktatási forma ezt a folyamatot már a graduális képzés során nagyban előkészíti, elősegíti. Jelentősége a posztgraduális (rezidensi, központi gyakornoki) képzésben és a szakorvos-továbbképzésben egyaránt meghatározó.

\section{Az egészségügyi szimulációs oktatás rövid története}

Az egészségügyi képzésben a szimuláció, mint módszertan, több évszázados múltra tekint vissza. Amikor ez a tudományterület szóba kerül, a leginkább az alapszintú, illetve emelt szintû újraélesztés (BLS és ALS) demonstrálása merül fel bennünk. Az újraélesztés, mint folyamat, már a Bibliában is megjelenik, és a történelem során több irodalmi, múvészeti alkotásban is feltünik $[11,12]$. Anatómiai modelleket, szemléltető eszközöket jóval a ma ismert oktatási eszközök megjelenése előtt készített az emberiség szerte a világon, például a XVII. században már komplett szülészeti és nőgyógyászati modelleket alkottak meg [13]. Az egészségügyi szimuláció lendületes fejlődésnek a XXI. században indulhatott, a tudomány elsősorban a múanyagipar és a számítástechnika - rohamos fejlődésének köszönhetően [14]. Ennek eredményeképpen az egészségügyi szimulációs oktatás ma már messze túlmutat a BLS-technikák elsajátításán.

Az egészségügyi szimuláció történetének leghíresebb, újraélesztést oktató modelljét 1958-ban alkották meg [4]. A „Resusci Anne” tette lehetővé első ízben a költséghatékony és széles körű oktatást a cardiopulmonalis resuscitatio területén - 1960-tól rendszeresen szerveztek kurzusokat a segítségével. A modell - melynek első változata a „Szajna Ismeretlen Asszonya” (L'Inconnue de la Seine) halotti maszkja alapján készült - anatómiai pontossága, valósághúsége az évtizedek alatt sokat fejlődött [15].

Az 1960-as években megjelent az első, számítógéppel összekötött, komplex páciensszimulátor, a Sim One, mely technikai igényei és ára miatt nem tudott széleskörüen elterjedni [16]. Ez a modell már képes volt a légzés és a vérkeringés imitálására, múk ödött a pupillája, négy különböző gyógyszert be lehetett adni neki virtuálisan, emellett két orvosi gáz (oxigén, nitrogén-oxid) érzékelésére is alkalmas volt [4].

$\mathrm{Az}$ akadémiai szférában is jelentős fejlesztések történtek, mint a CASE- (comprehensive anesthesia simulation environment) és a GAS- (Gainesville anesthesia simulator) rendszer $[17,18]$. Mindkét fejlesztés alapvető fontosságú volt a szimulátoroknak a technológiai, valamint a szimulációs oktatásnak a metodikai fejlődésében [19]. A CASE a későbbiek során MedSim néven került piacra, míg a GAS a METI cég (Medical Education Technologies, Inc.) alapjait teremtette meg. Később ezzel mint

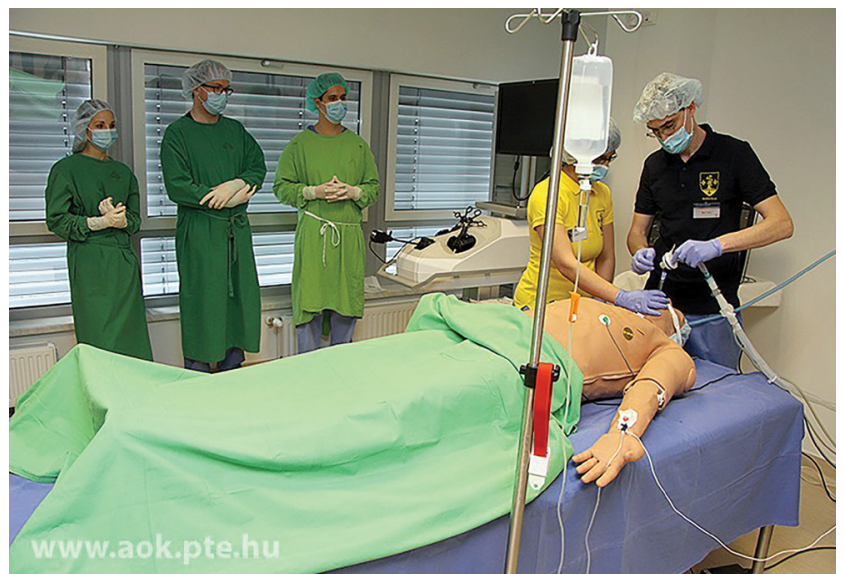

1. ábra

| CAE METIman prehospitális HIFI-szimulátoron intubálás, lélegeztetés demonstrálása

Forrás: Pécsi Tudományegyetem, Általános Orvostudományi Kar, Szimulációs Oktatási Központ, Verébi Dávid, 2016. március 1 .

HIFI = magas hűségű

CAE- (Canadian Aviation Electronics, Inc.) termék találkozhatunk (1. ábra).

Az első ismert kísérletek az egészségügyi oktatás és informatika ötvözésére 1961-ben már megkezdődtek, lyukkártyás technológiával és ma kezdetlegesnek tekinthető programnyelvekkel [20]. Az 1980-as években az infokommunikációs technológia, a háromdimenziós (3D) megjelenítés rohamléptékben kezdett fejlődni. A terület fontosságát korán, már az 1990-es évek végén felismerték, fóleg az invazív beavatkozások oktatása és a mútéti tervezés területén [21]. A szimulációs oktatás szorosan összefügg a ,játékosítással” ( gamification”), éppen ezért nem is meglepő, hogy az első ilyen „játékok” már az 1980-as években megjelentek - ezek lehetőséget adtak sebészeti beavatkozások (aortaaneurizma-mútét, vesekő-eltávolítás, vakbélgyulladás ellátása) játékos szemléletű oktatására, vizualizációjára [22, 23].

E területek fejlődésével alakult ki az egészségügyi szimulációs felsőoktatás napjainkban leginkább elfogadott nómenklatúrája, módszertana és eszközös háttere. A jelen közlemény a nemzetközi szakirodalom alapján tesz kísérletet a legfontosabb eszközök, eszközcsoportok bemutatására, a jövőben potenciálisan használható technológiák ismertetésére, összhangban a magyarországi szimulációs oktatási hálózat bemutatásával és a már rendelkezésre álló jó gyakorlatokkal. Bemutatjuk a hazai „Szimulációs Oktatási Hálózat” fejlesztési terveit, szakmai célkitűzéseit, valamint ismertetjük a szimulációs oktatást érintő, technológiai szempontú fejlesztési irányvonalakat is. Célkitüzésünk, hogy a területen hazánkban is megszilárduljon az összefogott, tudományos alapokon nyugvó, szakmailag koherens együttmúködés a szimulációs oktatásban érdekelt szereplők között. 


\section{A szimulációs oktatás eszközös háttere}

A szimulációs eszközök, demonstrációs megoldások technológiai szempontú csoportosítására jelenleg nincs egységes, nemzetközi klasszifikáció. A legtöbbször hivatkozott, David Gaba által javasolt felosztás az eszközök, technológiák csoportosítására a következő [24]:

1) Szóbeli szerepjáték: szituációk eljátszása kötetlen formában.

2) Standardizált beteg: színészek, akik meghatározott lépések szerint szimulálnak egy tünetegyüttest.

3) Részfeladat-szimulátor: feladat, intervenció, diagnosztikus lépés elvégzésére szolgáló eszköz (például rectalis digitális vizsgálat szimulátora).
4) Digitalizált beteg: a páciens kezdeti paraméterei, kórtörténete, a diagnosztikai és intervenciós lépések szoftver segítségével adhatók meg. Kiegészülhet fizikai szimulátorokkal, virtuális valóságon (VR) és kiterjesztett valóságon (AR) alapuló eszközökkel.

5) Elektronikus páciens: hardveres és szoftveres elemeket is tartalmazó szimulátor. Lehet VR- és AR-alapú is.

Guillaume Alinier egy másik csoportosítást javasolt [25], ezt a 2. táblázat foglalja össze.

A magyar nyelvű szakirodalomban jelenleg viszonylag kevés publikáció áll rendelkezésre, ezért a tudományterület hazai népszerüsítése graduális és posztgraduális szinten is elengedhetetlen - ez egyben a közelmúltban megalakult Magyar Egészségügyi Szimulációs Társaság egyik alapvető célkitüzése [26-29].

2. táblázat Az egészségügyi szimulátorok, technológiák Guillaume Alinier által javasolt, technológiai szempontú felosztása. Átvéve, fordítva: [25, 29]

\begin{tabular}{|c|c|c|c|c|c|c|}
\hline $\begin{array}{l}\text { A szimuláció } \\
\text { technológiai } \\
\text { szintje }\end{array}$ & 0 . szint & 1. szint & 2. szint & 3. szint & 4. szint & 5. szint \\
\hline $\begin{array}{l}\text { Szimulációs } \\
\text { technika, } \\
\text { technológia }\end{array}$ & $\begin{array}{l}\text { Írásbeli szimuláció } \\
\text { (toll-papír), } \\
\text { páciensmenedzs- } \\
\text { ment-probléma, } \\
\text { képek }\end{array}$ & $\begin{array}{l}\text { 3D modell, } \\
\text { szemléltetőeszköz, } \\
\text { alacsony hűségű } \\
\text { szimulátorok, } \\
\text { részfeladat-szimulá- } \\
\text { tor }\end{array}$ & $\begin{array}{l}\text { „Képernyőalapú” } \\
\text { szimulátorok: } \\
\text { szimulációs } \\
\text { szoftverek, videók, } \\
\text { digitális adathordo- } \\
\text { zók, VR-megoldá- } \\
\text { sok }\end{array}$ & $\begin{array}{l}\text { Standardizált } \\
\text { páciensszimuláció: } \\
\text { valós páciens vagy } \\
\text { „betegszínészek”, } \\
\text { szerepjáték }\end{array}$ & $\begin{array}{l}\text { Emelt szintû } \\
\text { páciensszimuláto- } \\
\text { rok: számítógép- } \\
\text { vezérelt, progra- } \\
\text { mozható eszközök, } \\
\text { általában teljes } \\
\text { testtel }\end{array}$ & $\begin{array}{l}\text { Interaktív } \\
\text { páciensszimuláto- } \\
\text { rok: számítógép- } \\
\text { vezérelt, teljes } \\
\text { alakos, interaktív } \\
\text { szimulátorok } \\
\text { („HIFI-” - magas } \\
\text { hûségû - szimulá- } \\
\text { torok) }\end{array}$ \\
\hline $\begin{array}{l}\text { A kivitelezés } \\
\text { módja szerint }\end{array}$ & Hallgatóközpontú & $\begin{array}{l}\text { Hallgató- vagy } \\
\text { oktatóközpontú }\end{array}$ & $\begin{array}{l}\text { Hallgató- vagy } \\
\text { oktatóközpontú }\end{array}$ & $\begin{array}{l}\text { Hallgató- vagy } \\
\text { oktatóközpontú }\end{array}$ & $\begin{array}{l}\text { A leginkább } \\
\text { oktatóközpontú }\end{array}$ & $\begin{array}{l}\text { A leginkább } \\
\text { hallgatóközpontú }\end{array}$ \\
\hline $\begin{array}{l}\text { Fejlesztendő } \\
\text { készségek }\end{array}$ & Passzív, kognitív & Pszichomotoros & Interaktív, kognitív & $\begin{array}{l}\text { Pszichomotoros, } \\
\text { kognitív, interper- } \\
\text { szonális }\end{array}$ & $\begin{array}{l}\text { Pszichomotoros, } \\
\text { kognitív, interper- } \\
\text { szonális }\end{array}$ & $\begin{array}{l}\text { Pszichomotoros, } \\
\text { kognitív, interper- } \\
\text { szonális }\end{array}$ \\
\hline $\begin{array}{l}\text { Szükséges } \\
\text { infrastruktúra }\end{array}$ & Tanterem & $\begin{array}{l}\text { Tanterem vagy } \\
\text { klinikai oktatóte- } \\
\text { rem }\end{array}$ & $\begin{array}{l}\text { Tanterem vagy } \\
\text { multimédiás/ } \\
\text { számítógép terem }\end{array}$ & Szcenáriótól függő & $\begin{array}{l}\text { Skill-labor vagy } \\
\text { szimulált kórházi } \\
\text { körülmények }\end{array}$ & $\begin{array}{l}\text { Szimulációs } \\
\text { központ valós } \\
\text { berendezésekkel, } \\
\text { audiovizuális } \\
\text { rendszerrel }\end{array}$ \\
\hline
\end{tabular}

\begin{tabular}{|c|c|c|c|c|c|c|}
\hline $\begin{array}{l}\text { A leggyako- } \\
\text { ribb oktatási } \\
\text { cél }\end{array}$ & $\begin{array}{l}\text { Páciensmenedzs- } \\
\text { ment-oktatás, } \\
\text { diagnosztika }\end{array}$ & $\begin{array}{l}\text { Demonstráció, } \\
\text { gyakorlati } \\
\text { készségek }\end{array}$ & $\begin{array}{l}\text { Kognitív készségek, } \\
\text { páciensmenedzs- } \\
\text { ment, interperszo- } \\
\text { nális készségek }\end{array}$ & $\begin{array}{l}\text { A } 2 \text {. szint kiegészít- } \\
\text { ve: fizikális } \\
\text { vizsgálat, diagnosz- } \\
\text { tika }\end{array}$ & $\begin{array}{l}\text { A 3. szint kiegészít- } \\
\text { ve: intervenciós } \\
\text { lépések, teljes } \\
\text { egészségügyi ellátás }\end{array}$ & A 4. szinttel azonos \\
\hline Hátrányok & $\begin{array}{l}\text { Nem valósághü, } \\
\text { nincs közvetlen } \\
\text { visszacsatolás }\end{array}$ & $\begin{array}{l}\text { Limitált számú } \\
\text { oktatható készség, } \\
\text { az interaktivitás } \\
\text { hiánya }\end{array}$ & $\begin{array}{l}\text { Nem valósághű } \\
\text { környezet, } \\
\text { szoftverek } \\
\text { ismeretének hiánya, } \\
\text { számítógépes } \\
\text { igények }\end{array}$ & $\begin{array}{l}\text { Csak kis létszámú } \\
\text { hallgató, nem lehet } \\
\text { intervenciót } \\
\text { végezni (kivéve, ha } \\
\text { kiegészül fizikai } \\
\text { trénerrel), } \\
\text { felkészült páciensek }\end{array}$ & $\begin{array}{l}\text { Programozás } \\
\text { szükségessége, } \\
\text { eszközök, } \\
\text { szoftverek ismerete, } \\
\text { szükséges lehet } \\
\text { páciensmonitor } \\
\text { alkalmazása }\end{array}$ & $\begin{array}{l}\text { Költség (fóleg a } \\
\text { környezet és a } \\
\text { szimulátor), több } \\
\text { eszköz szükséges, } \\
\text { eszközök ismerete, } \\
\text { általában nem } \\
\text { mobilizálható }\end{array}$ \\
\hline Előnyök & $\begin{array}{l}\text { Költséghatékony, } \\
\text { kevesebb oktatóval } \\
\text { is megvalósítható }\end{array}$ & $\begin{array}{l}\text { Mobil eszközök } \\
\text { elérhetők, kevés } \\
\text { oktató szükséges, } \\
\text { csökkenti a páciens } \\
\text { diszkomfortját }\end{array}$ & $\begin{array}{l}\text { Viszonylag } \\
\text { költséghatékony, } \\
\text { kis létszámú oktató } \\
\text { is elég, az } \\
\text { öntanulás, } \\
\text { önképzés } \\
\text { lehetősége, } \\
\text { azonnali visszacsa- } \\
\text { tolás szoftver által }\end{array}$ & $\begin{array}{l}\text { Nagyon magas } \\
\text { valósághűség, } \\
\text { alapvető fontosságú } \\
\text { a kommunikációs } \\
\text { készségekhez, } \\
\text { multiprofesszionális } \\
\text { gyakorlatok }\end{array}$ & $\begin{array}{l}\text { Magas valósághú- } \\
\text { ség, a készségek } \\
\text { széles köre } \\
\text { oktatható, } \\
\text { a hallgatók } \\
\text { teljesítménye } \\
\text { rögzíthetó, } \\
\text { multiprofesszionális } \\
\text { gyakorlatok }\end{array}$ & $\begin{array}{l}\text { Valósághú élmény, } \\
\text { a készségek széles } \\
\text { köre oktatható, } \\
\text { a hallgatók } \\
\text { teljesítménye } \\
\text { rögzíthető, } \\
\text { multiprofesszionális } \\
\text { gyakorlatok, valós } \\
\text { klinikai eszközök- } \\
\text { kel kiegészíthető }\end{array}$ \\
\hline
\end{tabular}

3D = háromdimenziós; HIFI = magas hűségű; VR = virtuális valóság 


\section{Innovatív megoldások az egészségügyi szimulációban}

Az oktatásmódszertani és -technikai fejlesztések számos új megoldást kínálnak, melyek az egészségügyi szimulációs oktatásban is megjelennek. A széleskörüen vizsgált és jelentős oktatásmódszertani eredményeket ígérő technológiák közé tartozik a 3D nyomtatás, a VR-, valamint az AR-alapú megoldások, melyekkel szinte minden nagyobb szimulációs oktatási központban találkozhatunk.

A VR és az AR a köztudatban szinonimaként szerepelnek, de a két fogalom nem ekvivalens. Míg a VR-technológiák célja a valóság megváltoztatása, a felhasználó új valóságba helyezése, addig az AR-technológiák hozzáadnak különböző tartalmakat a felhasználó által észlelt valósághoz.

A 3D nyomtatási és más, additív gyártástechnológiák ma már az élet szinte minden területén jelen vannak, legyen szó háztartási vagy ipari felhasználásról, de egyre gyakrabban találkozhatunk velük az egészségügyi ellátásban és felsőoktatásban is [30].

A hazai egyetemeken már rendelkezésre álló 3D nyomtatási és vizualizációs kapacitások is nagyban segíthetik a szimulációs központok múködését. Oktatási célú, virtuális 3D modellek készítésével digitális oktatási tartalmak (melyek akár hagyományos, akár AR/VR eszközökön megjeleníthetők) és fizikai modellek egyaránt fejleszthetők. Ezek jellemzően 'open-source', szabad hozzáférésû́ modellekből származnak, de képalkotó eszközök DICOM-állományából is szegmentálhatók. A 3D nyomtatási technológiák emellett sok esetben kiválóan alkalmazhatók a szimulátorok cserélhető és fogyó alkatrészeinek pótlására is. Jól használhatók az anatómiai ok- tatásban, májsebészeti oktató- és tervezőeszközök készítésében, de akár magas húségú szívsebészeti modellek készítésében [31-34]. Hazánkban is sikeresen alkottak meg modelleket ezen eljárás segítségével, többek között az intraossealis folyadékpótlás oktatására. E lehetőségek szélesebb körü elterjedésének elengedhetetlen feltétele a megfelelő interdiszciplináris kutató- és fejlesztőcsoportok jelenléte, elsősorban az orvostudományi és múszaki területekről. Fontos tényező emellett a fejlesztést végző egységek (a 3D központok és skillközpontok) közötti szoros szakmai együttmúködés.

A VR az ember-gép kapcsolatoknak olyan típusa, amely lehetôvé teszi a felhasználó számára, hogy a valós teret és érzékelést kiegészítse és/vagy helyettesítse a számítógép által generált vizuális, audiovizuális vagy taktilis információkkal $[35,36]$. Ez korunk egyik legdinamikusabban fejlődő múszaki irányvonala. Az ellátás területén a leginkább a rehabilitációban és a pszichológia, pszichiátria területén terjedt el. Az egészségügyi szakdolgozók és orvosok képzésében több aspektusával is találkozhatunk. Az egyszerúbb megoldások videójátékhoz hasonló szoftverek, amikor a felhasználó egy számítógép segítségével kerül a virtuális térbe, és ott 3D modellek segítségével tanul. Ennek egyik példája az anatómiai oktatás vagy orvosi eszközök (például altatógépek, ultrahang) kezelésének oktatása virtuális környezetben [37]. A VRkörnyezet kiegészíthető haptikus (erő-visszacsatolásos) eszközökkel, ekkor a taktilis visszajelzés is megvalósul [38]. Ezt általában komplexebb szimulátorok esetében, például laparoszkópos, endoszkópos trénereknél alkalmazzák, ahol a modellezett mútét során a tanuló a valóságnak megfelelően „érzi” az egyes struktúrákat (2. ábra) $[39,40]$. Más felhasználási területen haptikus kesztyúket
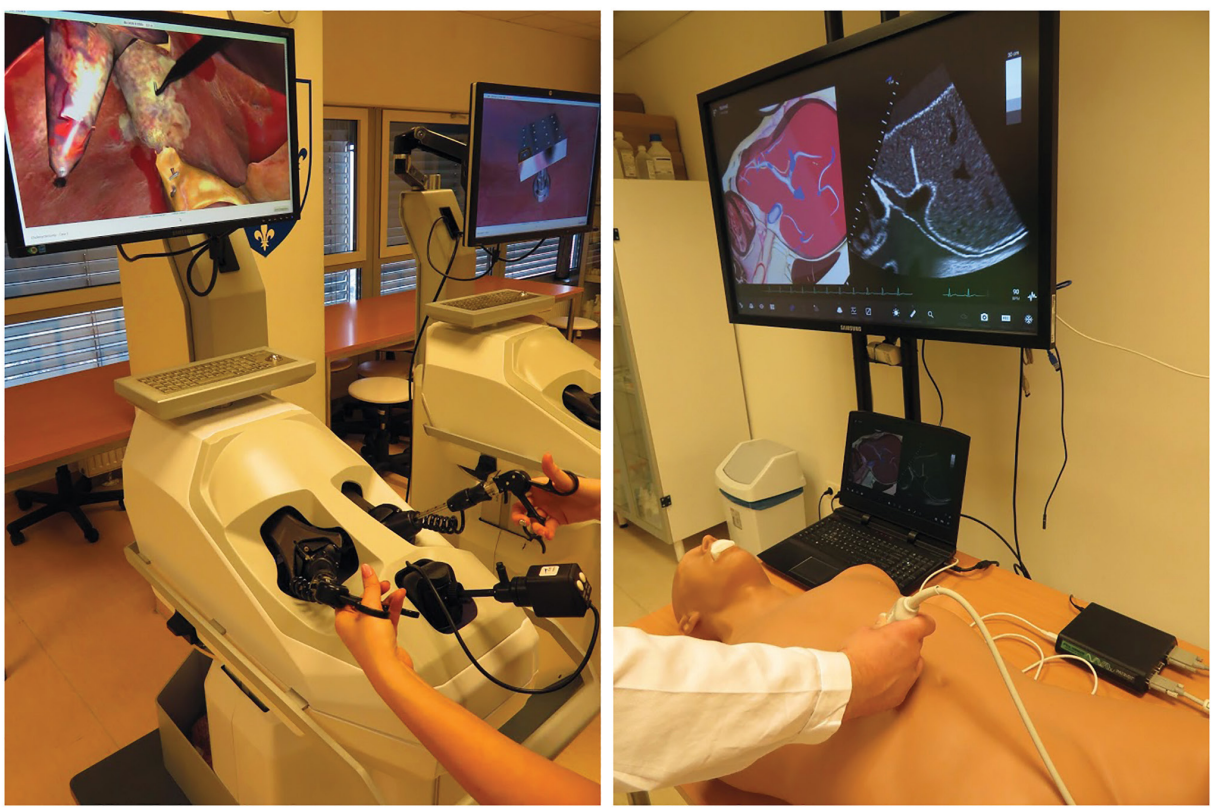

2. ábra

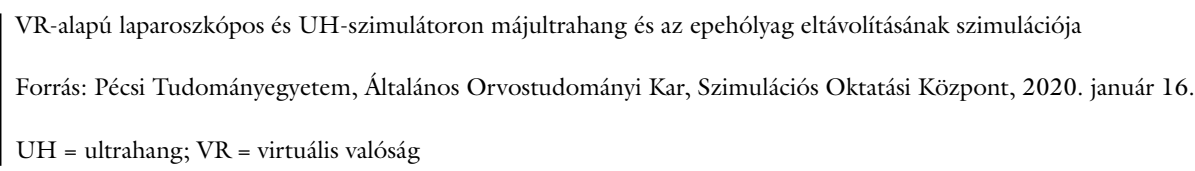


alkalmaznak, melyek a fizikális vizsgálatok oktatását teszik valósághúbbé [38].

Az AR-alapú technológiai megoldások leglényegesebb jellemzője, hogy a valós fizikai teret módosítják számítógép által generált elemekkel, így segítve egyes folyamatok, struktúrák bemutatását [41]. A fó különbség a VRrel szemben, hogy az AR-technológiák önmagukban képesek valós videók, 3D modellek és képek megjelenítésére, akár szerkesztetlen, akár annotált (jelölt) formában [42]. A megjelenítési oldalon AR-szemüvegekkel találkozhatunk, mely a felhasználó számára „odavetíti” az adott 3D tartalmat, de léteznek okostelefont is alkalmazó szoftverek. Az AR-t egyre szélesebb körben használják az egészségügyi szimulációs oktatásban, és egyre több prototípusról és fejlesztésról beszélhetünk [43, 44]. Leginkább a sebészeti és az anatómiai oktatás, illetve a képalkotási módszerek elsajátítása során találkozhatunk velük $[45,46]$.

\section{Az oktatást segítő rendszerek a szimulációs oktatási központokban}

A szimulációs oktatási központok jelentős hányada rendelkezik az oktatást támogató informatikai rendszerrel. Az egyszerúbb esetekben ezek a belső informatikai hálózat kialakítását jelentik, sok helyen találkozhatunk azonban komplett audiovizuális rendszerrel és 'e-learning' tananyagot kezelő rendszerrel.

Az LCMS-ek (learning and content management system) az oktatási tevékenységet támogatják azáltal, hogy lehetőséget adnak tananyagok kezelésére, szerkesztésére, emellett teljes oktatási tematikák átadására és ezek számonkérésére is alkalmasak lehetnek. Egyes szoftverek az oktatói munka véleményezésére is alkalmas (feedback), minőségbiztosítási funkciót is tartalmaznak. Az országos Skill Labor Hálózatban ezt a feladatot az Ilias Képzés Adminisztráció (ILKA - egyedi, az ÁEEK által fejlesztett rendszer) látja el, a kórházi rendszerekkel összhangban.

$\mathrm{Az}$ audiovizuális rendszer egy skill-labor esetében telepített vagy áthelyezhető kamerákból, illetve az ezeket kezelő szoftverből és szerverből áll. A rendszer alkalmas a szimulációk rögzítésére, az elkészült videók szerkesztésére, visszajátszására; az esetmegbeszélések során és a kommunikációs skillek oktatásakor alapvető fontossággal bír. A rendszerek a kiindulópontjai lehetnek a digitális tananyagfejlesztésnek és tartalomgyártásnak is. A hazai szimulációs oktatási rendszerben ezt a SZOTA (Szimulációs Oktatást Támogató Audiovizuális Rendszer) támogatja (az országos Skill Labor Hálózatban: CAE Learning Space $\left.^{\mathrm{TM}}\right)$.

\section{Magyarország szimulációs oktatási hálózata}

$\mathrm{Az}$ országos szintû EFOP-4.2.1. (EFOP-4.2.1-162017-00008. számú) és EFOP-4.2.2. (EFOP-4.2.2.-162017-00001. számú, „Skill laborok fejlesztése” címü) pályázati konstrukciónak köszönhetően a magyarországi egészségügyi szimulációs oktatás soha nem látott mértékű fejlesztésen eshetett át. Az infrastrukturális, a személyi és az eszközállományt tekintve jelentős beruházások történtek, melyek megalapozták egy országos, átfogó szakmai, oktatási hálózat kialakítását. Célkitüzés volt az egészségügyi felsőoktatásban tanulók, illetve az ellátórendszerben dolgozók hosszú távú és folyamatos készségfejlesztésének biztosítása, ezáltal pedig a betegbiztonság, valamint a népességszintû egészségnyereség növelése.

Az országos szimulációs hálózat alapkoncepciója az orvosképző egyetemeken létrehozott skillközpontok köré szerveződő, megyei oktató kórházi skill-laborok megalapítása volt. A budapesti képzési helyeket - tekintettel arra, hogy nem konvergenciarégióba tartoznak ez a fejlesztés nem érintette ebben a ciklusban. Az egyetemi központokban mind a graduális, mind a posztgraduális készségek teljes körú oktatása, illetve egyetemenként úgynevezett speciális képzési portfólió létrehozása is a szakmai program tartalmát képezte. Ezzel szemben az oktató kórházakban domináns az alapvető orvosi ismeretek, illetve szakdolgozói készségek oktatása. Ez a bontás az eszközök és a képzések kapcsán egyaránt nyomon követhető (3. táblázat).

A hazai szimulációs oktatást biztosító intézményekben az oktatói hátteret elsősorban az egyetemek alkalmazásában álló, betegellátást végző klinikai szakemberek biztosítják, míg a kisebb kórházi centrumok esetében az ellátóintézmények szakemberei. A teljes állású oktatói státuszok Magyarországon nem jellemzők. Ez a trend összhangban van a nemzetközi gyakorlattal, bár a nagyobb központok esetében előfordulhat, hogy minimális létszámú saját oktatói bázis rendelkezésre áll. Az oktató kórházi szimulációs tevékenységet hazánkban az egyete-

\begin{tabular}{l|l} 
3. táblázat & $\begin{array}{l}\text { Az EFOP-4.2.1. (EFOP-4.2.1-16-2017-00008.) és EFOP- } \\
\text { 4.2.2. (EFOP-4.2.2.-16-2017-00001. sz. „Skill laborok fejlesz- } \\
\text { tése”) számú pályázati konstrukció során kialakított szimulációs } \\
\text { oktatási hálózat }\end{array}$
\end{tabular}

\begin{tabular}{ll}
\hline Egyetemi központok & Oktató kórházak \\
\hline 1. Debrecen & 15. Tatabánya \\
& 16. Salgótarján \\
& 17. Eger \\
& 18. Miskolc \\
& 19. Nyíregyháza \\
\hline
\end{tabular}

\begin{tabular}{ll}
\hline 2. Pécs & 4. Szombathely \\
& 5. Zalaegerszeg \\
& 6. Győr \\
7. Kaposvár & 8. Veszprém \\
& 9. Szekszárd \\
\hline 3. Szeged & 10. Székesfehérvár \\
& 11. Kecskemét \\
12. Szolnok & 13. Hódmezővásárhely \\
14. Békéscsaba
\end{tabular}

EFOP $=$ Emberi Erőforrás Fejlesztési Operatív Program 
mi központok szakértői segítik, támogatják mind módszertani, mind technológiai szempontból.

A skillalapú oktatás helye a curriculumban országosan nagyjából egységes képet mutat graduális szinten. Az alapozó képzésben jellemzően az ápolástani ismeretek, valamint az elsősegéllyel (BLS) kapcsolatos készségek jelennek meg, egyes esetekben elméleti ismeretek gyakorlati bemutatása mellett (például biofizika - ultrahang vagy EKG demonstrációja). A preklinikai modulban a mútéttani oktatásban szerepel hangsúlyosan a szimuláció, míg a klinikai képzésben számos helyen megjelenik. A rendelkezésre álló eszközpark alapján az egyetemeken főleg a szülészet-nőgyógyászat, az általános sebészet, az urológia, a fül-orr-gégészet, az aneszteziológia és intenzív terápia, valamint az oxiológia oktatását tudják támogatni graduális szinten. A posztgraduális képzési portfólióban szintén teret nyert a skillképzés, itt azonban az egyes központok erősségei jelennek meg inkább. Fontos eredmény, hogy a szakképzési programok közül a sebészet törzsképzési programjában egy hónapos skilltréning elóírásra került. A számonkérések rendszere szintén helyi sajátosságokat követ: van, ahol az adott kurzusba integráltan, van, ahol külön vizsgarészként jelenik meg, közös jellemző azonban, hogy sok esetben bevonja a központokba telepített audiovizuális rendszert (debriefing, minőségbiztosítás). Ezek a rendszerek nemcsak a vizsgáztatásban, hanem a tananyagszerkesztésben is segítséget nyújtanak, például oktatóvideók elkészítése során. A digitális tananyagok mellett egyre inkább megjelennek fizikai modellek fejlesztését is célzó projektek, erre jó gyakorlat lehet a 3D nyomtatási technológiák megjelenése Budapesten, Debrecenben, Pécsen és Szegeden egyaránt.

Az orvosképző egyetemek közötti szakmai konzultáció sikeresen megkezdődött egy egységesebb, szakmailag koherens skillképzési rendszer kialakítása érdekében. Ebben segítség volt az EFOP-4.2.2. számú pályázatban létrejött tananyag (Módszertani kézikönyv skill képzésekhez), valamint a képzők képzését biztosító, BLSkészségeket oktató 4 lépcsős módszer országos szintú bevezetése [47, 48]. A részletek kidolgozása, a megfelelő grémiumok megszólítása azonban még nem történt meg teljes egészében - ennek legfőbb nehezítő tényezője a szakterület viszonylagos újdonsága, a leginkább a fejlesztések vonatkozásában. Fontos, hogy a szimulációs oktatás módszertani előnyei, a technológia nyújtotta lehetőségek még szélesebb körben bemutatásra és elfogadásra kerülhessenek. E lépések esszenciálisak a megfelelő képzési szintekhez és követelményekhez alkalmazkodó, szakmailag hiteles curriculum kialakításához.

Az országosan kialakított infrastruktúra lehetővé teszi az általános orvosi gyakorlatban fontos beavatkozások szimulációs alapú gyakorlását és számonkérését, valamint széles körű oktatástechnikai modellek és magas hûségű páciensszimulátorok, ultrahang- és laparoszkópszimulátorok, orvostechnikai eszközök állnak rendelkezésre az egyes diszciplínákra jellemző speciális beavatkozások szi- mulálására. Az egyetemi központokban meghatározásra került az a szakmai tartalom, amely egyfajta speciális szakterületként jelenik meg mind az infrastruktúra, mind a szimulátorok és a szakemberek szintjén.

\section{Debreceni Egyetem}

A Debreceni Egyetem ÁOK skilloktatást nyújtó két szervezeti egysége a Sebészeti Mútéttani Tanszék és az Interaktív Orvosi Gyakorlati Központ, mely 2012-ben nyitotta meg kapuit.

A Sebészeti Mütéttani Tanszéken a kutatómunka mellett a sebészeti alapkészségek, sebészeti mútéttani, mikrosebészeti és laparoszkópos sebészeti technikák oktatása történik, emellett speciális tréningekre nyújt lehetőséget több diszciplína számára oktatómütők elérhetőségével.

Az Interaktív Orvosi Gyakorlati Központ a Kar egyik szolgáltató (oktatást szolgáló) szervezeti egysége, amely helyet és eszközt biztosít az egyetem intézeteiben zajló gyakorlati oktatáshoz, valamint szakdolgozók és oktatók továbbképzéseihez, hazai és nemzetközi kurzusok lebonyolításához. Speciális szakterületként megjelenik a mikrosebészet és a laparoszkópos sebészet, valamint a szemsebészeti szimulátornak köszönhetően a szemészeti szakképzésbe is bevonható a szimulációs oktatás. Jelentős infrastruktúra- és eszközparkbővítés valósult és valósul meg az EFOP-4.2.1-16-2017-00015. számú, „A Debreceni Egyetem felsőoktatási infrastruktúra fejlesztése a gyakorlati és szakmai képzés megújítása érdekében" című és az EFOP-4.2.2-16-2017-00001. számú, "Skill laborok fejlesztése" címú elnyert pályázatok keretein belül. Megújulnak az oktatótermek és a gyakorlómútők, jelentősen bővül az épületek alapterülete, új szimulációs termekkel gazdagodva.

\section{Pécsi Tudományegyetem}

A „MediSkillsLab” 2016. március 1-jén kezdte meg múködését. A létesítmény sikerességét jól mutatja, hogy 2017 óta átlagosan 1500, 45 perces foglalkozás megtartására került sor minden félévben. Az EFOP-4.2.2. és 4.2.1. számú pályázatoknak köszönhetően a MediSkillsLab is jelentős fejlesztéseken esik át. A pécsi fejlesztés homlokterében a múveleti medicina koncepciója áll, melynek célja, hogy a múveleti területen dolgozó szakemberek (tûzoltók, katasztrófavédők, rendőrök, katonák stb.) részére nyújtson szakszerű ismereteket az első vonalbeli ellátásról. A koncepció következő lépése az akut ellátást követően a sürgős, klinikai beavatkozások gyakorlása, melyhez egy teljesen felszerelt tanmútő fog rendelkezésre állni, ahol kadávermútétek elvégzésére, új orvostechnológiai eszközök preklinikai tesztelésére is lehetőség lesz. Egy komplett VR/AR tanterem berendezésére is sor kerül, melynek során a piacon elérhető, aktuálisan legmodernebb VR/AR eszközök beszerzése valósul meg. A fejlesztés magában foglalja a fogorvosi 
szimulációs kapacitások kidolgozását és létrehozását is, biztosítva a kezdetekben megálmodott interdiszciplináris szemléletmódot.

\section{Semmelweis Egyetem}

Hazánk orvosképzésében a legnagyobb részt vállaló egyetem már a fentebb részletezett pályázati konstrukció előtt kialakította impozáns szimulációs infrastruktúráját. A Skill Centrum (KMOP-4.2.1/B-10-2011-0010. számú) pályázatot 2011-ben nyerte el a Semmelweis Egyetem; az Ernő utcai Semmelweis Szimulációs Központ átadására 2013-ban került sor, majd további 15 intézetben valósultak meg fejlesztések a projekt keretein belül. Fontos eleme volt a fejlesztéseknek egy audiovizuális rendszer kiépítése - mely az országban úttörőnek is tekinthető -, ez összeköti a vizsgálókat, mütőket az előadótermekkel. Ennek köszönhetően nagyobb hallgatóság előtt lehet interaktív, gyakorlatias oktatást végezni anélkül, hogy az a mütéti sterilitást veszélyeztetné. Az aneszteziológia és intenzív terápia, illetve az oxiológia jelenik meg hangsúlyos posztgraduális szakmai tartalomként, s ennek köszönhetően jól integrálható a szimulációs oktatás e diszciplínák szakképzési programjaiban.

\section{Szegedi Tudományegyetem}

A szegedi Általános Orvostudományi Karon 2006. szeptember 20-án került átadásra az ország első skillközpontja a „Gyakorlati Képzés és Készségfejlesztés az Egészségügyi Felsőoktatásban” ROP-projekt támogatásával, mely a Sebészeti Mútéttani Intézet (SMI) infrastruktúráján alapult. A fejlesztés számszerüsíthető eredményeiről 2005-ben számoltak be a szakterület első nemzetközi kongresszusán [49]. Az SMI által koordinált országos HEFOP-pályázattal a minimálisan invazív sebészeti szimuláció is lehetővé vált, majd szerkesztésükkel megjelentek az első hazai egyetemi „skills” tankönyvek magyar és angol nyelven [50-52].

A SZTE Orvosi Készségfejlesztési Központ („Szeged Skills”) átadása 2013-ban történt; a tanórák száma folyamatosan emelkedett a jelenlegi átlagosan évi 2500 hallgató 1800 oktatási óraszámig. A Központ A Részlegének fô profilja ma elsősorban a sürgősségi medicina, az itt rendelkezésre álló infrastruktúra (köztük egy mentőautó-szimulátor) biztosítja az oktatási hátteret a diszciplínák számára. 2018 végén nyitotta meg kapuit a "Szeged Skills" B Részlege, további távlatokat nyitva. A Mikrosebészeti Oktató Központ mellett átadásra került két teljesen felszerelt szimulációs műtőblokk, szülészeti-nőgyógyászati, sebészeti-intenzív terápiás, szakápolási és képalkotó-diagnosztikus gyakorlótermek. A speciális szakterületként megjelenő mikrosebészet jól integrálható az érsebészeti és az idegsebészeti rezidensképzésbe és szinten tartó szakvizsgaképzésekbe is.

\section{Megbeszélés}

A hazai orvosegészségügyi szimulációs oktatás jelentős fejlesztéseken esett át az elmúlt években, elsősorban eszközös és infrastrukturális szempontból. Országszerte sikeresen kialakításra kerültek egyszerúbb szemináriumi termek, demonstrációs egységek („dry lab”), kialakítás alatt állnak kisállat- és cadaver-mütők („wet lab”) és kiszolgálófacilitások, mint például az esetmegbeszélő (debriefing) vagy megfigyelö- (observer) termek. A telepített eszközpark jelentős, az egyes technikai és nem technikai készségek széles palettája oktatható. Az oktatást támogató informatikai rendszerek kiépítése sikeresen megkezdődött, illetve az innovatív oktatási elemek az egyetemeken megjelentek. Az országos hálózat sikeres múködését azonban csak a megfelelő szakemberállomány tudja hosszú távon biztosítani, így kiemelten fontos a folyamatos, szakszerú képzési programok szervezése, a szimulációs egységek tartalmi fejlesztése, az utánpótlás minél korábbi bevonása és a jó gyakorlatok, innovatív megoldások átgondolt, tervezett implementálása.

Anyagi támogatás: A közlemény megírása és a kapcsolódó kutatómunka anyagi támogatásban külön nem részesült. A közleményben bemutatott hálózat eszközparkjának és rendszerének kiépítése az EFOP-4.2.1-162017-00008. számú, „Pécsi Tudományegyetem infrastrukturális fejlesztése" címú, EFOP-4.2.2.-16-201700001. számú, „Skill laborok fejlesztése” pályázatok, a Pécsi Tudományegyetem „Tématerületei Kiválósági Program 2019 - Biomedical Engineering Projekt” keretében belül valósul meg (TUDFO/51757-1/2019ITM), melyekből R. Sz., N. N., B. M., N. B., M. P. a projekt szakmai megvalósításáért anyagi juttatásban részesült. Az országos fejlesztés megvalósulásában segítettek a TÁMOP-4.1.1/A-10/1KONV-2010-0016. számú „Munkaerőpiaci alkalmazkodás, gyakorlati képzőhelyek, intézményirányítás és hallgatói-oktatói szolgáltatások fejlesztése a Debreceni Egyetemen”, a TÁMOP-4.1.2.A/1-11/1-2011-0084. számú „Gyakorlati kompetenciák elsajátítását szolgáló, szimulációs modelleken alapuló, interaktív audiovizuális eszközökkel támogatott oktatási tananyagok fejlesztése az orvosképzésben”, az EFOP-4.2.1-16-2017-00015. számú „A Debreceni Egyetem felsőoktatási infrastruktúra fejlesztése a gyakorlati és szakmai képzés megújítása érdekében", továbbá az EFOP-4.2.2-16-2017-00001. számú „Skill laborok fejlesztése” elnevezésű pályázatok.

Szerzôi munkamegosztás: B. P. Z.: Irodalomkutatás, a kézirat szövegezése. T. L.: Irodalomkutatás, a kézirat szövegezése. R. Sz., N. N., B. M.: A kézirat szakmai véleményezése, közremúködés a szimulációs hálózat kialakításában. N. B., Ny. M.: A kézirat szakmai véleménye- 
zése. M. L.: Irodalomkutatás, a kézirat szakmai véleményezése. M. P.: Irodalomkutatás, a kézirat szövegezése, a kézirat szakmai véleményezése, közremúködés a szimulációs hálózat kialakításában.

Érdekeltségek: A szerzőknek nincsenek érdekeltségeik.

\section{Köszönetnyilvánítás}

Ezúton mondunk köszönetet a magyar államnak és az Európai Uniónak a magyarországi egészségügyi szimulációs oktatás, ezáltal pedig az orvos- és egészségügyi szakdolgozók képzésének kiemelt fejlesztéséért. Köszönet illeti az Állami Egészségügyi Ellátó Központot, hogy a hazai hálózatosodást érintő fejlesztés koordinátoraként, konzorciumvezetőjeként a munkálatokat lehetővé tette. Külön hálával tartozunk a hazai egészségügyi szimulációs oktatás támogatásáért, szakértői tevékenységéért a következő személyeknek: $d r$ Kovács Rita, dr. Horváth Kitti, dr. Hamar Attila, dr. Dénes Tamás, dr. Fritúz Gábor és Takács Laura.

\section{Irodalom}

[1] Al-Elq AH. Simulation-based medical teaching and learning. J Family Community Med. 2010; 17: 35-40.

[2] Issenberg SB, McGaghie WC, Hart IR, et al. Simulation technology for health care professional skills training and assessment. JAMA 1999; 282: 861-866.

[3] Jeffries PR. A framework for designing, implementing, and evaluating simulations used as teaching strategies in nursing. Nurs Educ Perspect. 2005; 26: 96-103.

[4] Bradley P. The history of simulation in medical education and possible future directions. Med Educ. 2006; 40: 254-262.

[5] Ker J, Mole L, Bradley P. Early introduction to interprofessional learning: a simulated ward environment. Med Educ. 2003; 37: 248-255.

[6] Kuznar KA. Associate degree nursing students' perceptions of learning using a high-fidelity human patient simulator. Teach Learn Nurs. 2007; 2: 46-52.

[7] Schiavenato M. Reevaluating simulation in nursing education: beyond the human patient simulator. J Nurs Educ. 2009; 48: 388-394.

[8] Brewer EP. Successful techniques for using human patient simulation in nursing education. J Nurs Scholarsh. 2011; 43: 311317.

[9] Ganley BJ, Linnard-Palmer L. Academic safety during nursing simulation: perceptions of nursing students and faculty. Clin Simulation Nurs. 2012; 8: e49-e57.

[10] Mompoint-Williams D, Brooks A, Lee L, et al. Using high-fidelity simulation to prepare advanced practice nursing students. Clin Simulation Nurs. 2014; 10: e5-e10.

[11] Paraskos JA. Biblical accounts of resuscitation. J Hist Med Allied Sci. 1992; 47: 310-321.

[12] Harris SB. The society for the recovery of persons apparently dead. Skeptic 1992; 1: 24-31.

[13] Owen H. Early use of simulation in medical education. Simul Healthc. 2012; 7: 102-116.

[14] Rosen KR. The history of medical simulation. J Crit Care 2008; 23: $157-166$

[15] Johnson DB. "L'Inconnue de la Seine” and Nabokov's Naiads. Comp Lit. 1992; 28: 224.

[16] Abrahamson S, Denson JS, Wolf RM. Effectiveness of a simulator in training anesthesiology residents. 1969. Qual Saf Health Care 2004; 13: 395-397.

[17] Gaba DM, DeAnda A. A comprehensive anesthesia simulation environment: re-creating the operating room for research and training. Anesthesiology 1988; 69: 387-394.
[18] Good ML, Gravenstein JS. Anesthesia simulators and training devices. Int Anesthesiol Clin. 1989; 27: 161-168.

[19] Cooper JB, Taqueti VR. A brief history of the development of mannequin simulators for clinical education and training. Postgrad Med J. 2008; 84: 563-570.

[20] Piemme TE. Computer-assisted learning and evaluation in medicine. JAMA 1988; 260: 367-372.

[21] Gross MH. Computer graphics in medicine: from visualization to surgery simulation. ACM SIGGRAPH Computer Graphics 1998; 32: 53-56.

[22] Vogel JJ, Vogel DS, Cannon-Bowers J, et al. Computer gaming and interactive simulations for learning: a meta-analysis. J Educ Comput Res. 2006; 34: 229-243.

[23] Kerfoot BP, Kissane N. The use of gamification to boost residents' engagement in simulation training. JAMA Surg. 2014; 149: 1208-1209.

[24] Gaba DM. The future vision of simulation in health care. Qual Saf Health Care 2004; 13(Suppl 1): i2-i10.

[25] Alinier G. A typology of educationally focused medical simulation tools. Med Teach. 2007; 29: e243-e250.

[26] Koppán Á, Eklicsné Lepenye K, Halász R, et al. Actor as a simulated patient in medical education at the University of Pécs. [A színész mint szimulált páciens az oktatásban a Pécsi Tudományegyetemen.] Orv Hetil. 2017; 158: 1022-1027. [Hungarian]

[27] Csóka M, Deutsch T. Innovative education: introduction of clinical simulation-based training at the Faculty of Health Sciences, Semmelweis University, Hungary. [A jövő útja: szimulátoros gyakorlati oktatás a Semmelweis Egyetem Egészségtudományi Karán.] Orv Hetil. 2011; 152: 27-33. [Hungarian]

[28] Borján E, Mészáros J, Rigó J Jr. Use of high-fidelity simulators for students' evaluation. [Valósághû́ páciensszimulátorok alkalmazása a hallgatói teljesítmény értékelésében.] Orv Hetil. 2015; 156: 1335-1340. [Hungarian]

[29] Borján EGy. Use of high-fidelity simulators in healthcare education. Doctoral thesis. [A magas hűségű (high-fidelity) szimulátorok alkalmazása az egészségügyi szakemberek képzésében. Doktori értekezés.] Semmelweis Egyetem, Patológiai Tudományok Doktori Iskola, Budapest, 2015. [Hungarian]

[30] Rengier F, Mehndiratta A, von Tengg-Kobligk H, et al. 3D printing based on imaging data: review of medical applications. Int J Comput Assist Radiol Surg. 2010; 5: 335-341.

[31] Lim KH, Loo ZY, Goldie SJ, et al. Use of 3D printed models in medical education: a randomized control trial comparing 3D prints versus cadaveric materials for learning external cardiac anatomy. Anat Sci Educ. 2016; 9: 213-221.

[32] McMenamin PG, Quayle MR, McHenry CR, et al. The production of anatomical teaching resources using three-dimensional (3D) printing technology. Anat Sci Educ. 2014; 7: 479-486.

[33] Zein NN, Hanouneh IA, Bishop PD, et al. Three-dimensional print of a liver for preoperative planning in living donor liver transplantation. Liver Transpl. 2013; 19: 1304-1310.

[34] Costello JP, Olivieri LJ, Krieger A, et al. Utilizing three-dimensional printing technology to assess the feasibility of high-fidelity synthetic ventricular septal defect models for simulation in medical education. World J Pediatr Congenit Heart Surg. 2014; 5: 421-426.

[35] Steuer J. Defining virtual reality: dimensions determining telepresence. J Commun. 1992; 42: 73-93.

[36] Laver KE, George S, Thomas S, et al. Virtual reality for stroke rehabilitation. Stroke 2012; 43: e20-e21.

[37] Nicholson DT, Chalk C, Funnell WR, et al. Can virtual reality improve anatomy education? A randomised controlled study of a computer-generated three-dimensional anatomical ear model. Med Educ. 2006; 40: 1081-1087.

[38] Ullrich S, Kuhlen T. Haptic palpation for medical simulation in virtual environments. IEEE Trans Vis Comput Graph. 2012; 18: $617-625$ 
[39] Panait L, Akkary E, Bell RL, et al. The role of haptic feedback in laparoscopic simulation training. J Surg Res. 2009; 156: 312 316.

[40] van der Meijden OA, Schijven MP. The value of haptic feedback in conventional and robot-assisted minimal invasive surgery and virtual reality training: a current review. Surg Endosc. 2009; 23: 1180-1190.

[41] Wu HK, Lee SW, Chang HY, et al. Current status, opportunities and challenges of augmented reality in education. Comput Educ. $2013 ; 62$ : 41-49.

[42] Shuhaiber JH. Augmented reality in surgery. Arch Surg. 2004; 139: 170-174.

[43] Kamphuis C, Barsom E, Schijven M, et al. Augmented reality in medical education? Perspect Med Educ. 2014; 3: 300-311.

[44] Zhu E, Hadadgar A, Masiello I, et al. Augmented reality in healthcare education: an integrative review. Peer J. 2014; 2: e469.

[45] Marescaux J, Rubino F, Arenas M, et al. Augmented-reality-assisted laparoscopic adrenalectomy. JAMA 2004; 292: 2214 2215 .

[46] Herron J. Augmented reality in medical education and training. J Electron Resour Med Libr. 2016; 13: 51-55.

[47] Herrmann-Werner A, Nikendei C, Keifenheim K, et al. "Best Practice" skills lab training vs. a "see one, do one" approach in undergraduate medical education: an RCT on students' longterm ability to perform procedural clinical skills. PLoS ONE 2013; 8: e76354.

[48] Dénes T, Hamar A, Horváth K, et al. (eds.) Methodological references for skill training. [Módszertani kézikönyv skill képzésekhez.] Állami Egészségügyi Ellátó Központ, Budapest, 2019. [Hungarian]

[49] Boros B, Kaszaki J, Szabó A, et al. The teaching of practical skills to undergraduate medical students in Hungary. In: Proceedings of the First International Clinical Skills Conference, Prato, 2005; pp. 218-219.

[50] Boros M. (ed.) Practical skills syllabus. Innovariant Ltd., Szeged, 2007.

[51] Boros M. (ed.) Monitoring in medical practice - basic medical skills. [Orvostechnika és monitorozás. Gyakorlati orvosi alapismeretek.] Medicina Könyvkiadó, Budapest, 2013. [Hungarian]

[52] Boros M. (ed.) Monitoring in medical practice - basic medical skills - textbook for medical students. Innovariant Ltd., Szeged, 2007.

(Maróti Péter dr., Pécs, Szigeti út 2., 7624 e-mail: peter.maroti@aok.pte.hu)

\section{"lucundum nihil est nisi quod reficit varietas." (Semmi sem esik jól, amit nem üdít fel a változatosság.)}

A cikk a Creative Commons Attribution 4.0 International License (https://creativecommons.org/licenses/by/4.0/) feltételei szerint publikált Open Access közlemény, melynek szellemében a cikk bármilyen médiumban szabadon felhasználható, megosztható és újraközölhető, feltéve, hogy az eredeti szerző és a közlés helye, illetve a CC License linkje és az esetlegesen végrehajtott módosítások feltüntetésre kerülnek. (SID_1) 